\title{
Selected Reference Books of 1995-1996
}

\section{Eileen Mcllvaine}

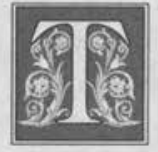

his article follows the pattern set by the semiannual series initiated by the late Constance $\mathrm{M}$. Winchell more than sixty years ago and continued by Eugene Sheehy. Because the purpose of the list is to present a selection of recent scholarly and general works, it does not pretend to be either well balanced or comprehensive. A brief roundup of new editions of standard works is provided at the end of the articles. Code numbers (such as AD540) have been used to refer to titles in the Guide to Reference Books, 11 th ed. (Chicago: ALA, 1996).

\section{National Bibliographies}

Cëská národní bibliografie: Knihy, disertace, periodika, clánky/Czech National Bibliography: Books, Journal Articles, Periodicals, Dissertations [CD-ROM]. Albertina icome, 1995- . Pricing information not available. (ISSN 1210-8995.) LC sn9533917. (Publisher's address: Albertina icome Praha; Revolucni 13; Praha 1, 110000 Czech Republic. Telephone: 0224-803-254).

Students of Eastern European affairs should be familiar with the ambitious series of national bibliographies published by the countries of the region, detailing not only the output of books and serials but also indexing articles in many periodicals, listing doctoral dissertations, and documenting various other types of publications. Sadly, this information resource has tended to be greatly underutilized, particularly by researchers in this country, because of the lack of easy or comprehensive indexes and the fragmentation of the data into many successive issues.

For this reason, the appearance of a CD-ROM publication of the kind reviewed here should be a cause for rejoicing among scholars in this field because it can provide a quantum leap in information about publications at a time when the opening up of the region and the freeing of its intellectual life are creating new demands in the West for access to publications from that part of the world.

The Czech National Library has begun issuing its various national bibliographies in electronic format (for the paper versions, see Guide AA600). The disk contains four separate databases: (1) a listing of books published in the Czech Republic between 1983 and 1993, and presented to the National Library under the mandatory deposit program (approximately 100,000 titles); (2) an index to articles published in the major newspapers and selected general interest, humanities, social science, and science journals of the Czech Republic between 1991 and 1994

Eileen Mcllvaine is Head of Reference and Collections, Butler Library, Columbia University; e-mail: mcilvain@columbia.edu. Although it appears under a byline, this list is a project of the reference departments of Columbia University Libraries, and notes are signed with the initials of one of the following staff members: Hal Grossman, Business Library; Nancy E. Friedland, Undergraduate Library; Mary Cargill, Olha della Cava, Robert H. Scott, Sarah Spurgin, Junko Stuveras, Butler Library.. 
(again something on the order of 100,000 entries); (3) a listing of all Czech Ph.D. dissertations and dissertations defended at the Czech Academy of Sciences from 1989 through 1992; and (4) a catalog of periodicals and newspapers published in the Czech Republic from November 1989 through 1993.

The search interface is well designed, and easy to learn and remember. Search forms (available in both English and Czech) enable retrieval using a variety of access points - author, title, place of publication, publisher, date, standard numbers, subject headings, keywords, and many more-both individually and in combination. A full range of logical and proximity operators may be used within any of those fields; truncation is possible to retrieve permutations of the same stem. Search terms must include diacritics (using the "v" and "'" before the accented letter), and subject headings and keywords must be in Czech, but the availability of an index for browsing every field means that a native command of Czech is not required for effective searching.

Users select from a number of different display and output formats and choose the specific fields to be included in either. Moreover, the records, although not in MARC format, are designed to be easily importable in MARC, which offers an interesting technical processing potential as well. One challenge for user institutions may be in dealing with the diacritics in printing and downloading, but the well-written, on-disk manual includes documentation for this purpose.

The ability to search for Czech language publications of all major types electronically represents a quantum leap for researchers interested in the study of this country or in obtaining Czech literature on other topics. This tool surely belongs in every major research institution providing support for advanced Czech studies. Indeed, it behooves those institutions to move soon to acquire such materials as a way of encouraging further publications of this kind, so important for the continuing development of East European studies in this country. The CDROM has had a very small distribution in this country, and there are indications that its future availability my depend on whether the publisher sees that it is a marketable product. The CD-ROM was originally priced at about $\$ 900$, but Albertina is reportedly entertaining the idea of a lower price to encourage more sales. Although this order of cost is more than most libraries have paid in the past for this information in print, the enormously improved access seems well worth the difference.

At a time when interest in the study of Eastern Europe is growing, thanks to the opening up of the countries of the former Soviet bloc to greater contact with the rest of the world and with the emergence of more varied and lively publishing industries in each of them, this type of enhanced access to bibliographic information from the region is most timely and desirable. Indeed, one can hope that this achievement will be imitated by more of the national libraries of the region.R.H.S.

\section{Dictionary}

Le Robert electronique DMW: Outil d'aide à la rédaction sur la base du Grand Robert de la langue française [CD-ROM]. Paris: Dictionnaires Le Robert, 1994. \$1,080. (ISBN 2-85036289-1.) (Supplied by Chadwyck Healey).

The "grand Robert" now residing on one CD-ROM disk contains all the works in the nine-volume Grand Robert de la langue française: Dictionnaire alphabétique et analogique de la langue française (1985; Guide AC334). The electronic version can be operated on MS-DOS, Macintosh, or Windows.

From a simple menu, one can browse through a word list of more than 99,000 words and search a word by either selecting from the list or typing the word into 
a box, using, if you wish, "joker" or wild characters. The joker works for left, right, and middle of a word for one character (using ?) or an indefinite number of characters (using *). The search result can be displayed in a brief or long format. From an entry, the user can go on to the etymology, synonyms, antonyms, homonyms, and derivatives; take a look at citations by clicking on a citation number; or jump to the article on any word in the entry. A table of conjugation for a verb in any mode and tense is available.

If unsure about spelling, the user can type the word phonetically and click the "orth[ographie]" button, and the database will search for word(s) with the same pronunciation. Pronunciation is given in all entries using the phonetic notation for which the table can be called up at a click of the menu button. The Robert has not yet gone for the multimedia format used by some dictionaries. At the moment, users cannot hear the word pronounced by a Comédie française actor or hear the bird in the entry sing.

The electronic dictionary comes with a database of quotations which can be searched separately. Each citation is composed of two elements: text and bibliographic reference. Each element can be searched using Boolean logic and/or a "joker," and the two may be combined to find a quotation(s) that contains one or more of the keywords. The quotation portion of the dictionary contains some 160,000 entries.

The dictionary can be set up to be used in a resident mode while writing a paper using another program. The text of both the dictionary and quotation entries can be copied into a document when this database is used in memory resident mode in conjunction with a word processor. There is a 300 -word limit to copying.

Recommended for academic and research institutions where the advanced level of the French language is spoken.-J.S.

\section{Religion}

Dictionnaire historique de la papauté. Ed. Philippe Levillain. [Paris]: Fayard, 1994. 1759p., 36p. of plates. 1,300FF. (ISBN 2-21302537-1.)

This work represents an important new reference tool on the history of the papacy for advanced scholars. Directed by an editorial board from the École française de Rome, and written by a collective of scholarly authors affiliated with various institutions primarily in France and Italy, it offers, in a single volume, approximately 700 articles covering all aspects of its subject. In addition to substantive entries for individual pontiffs (and anti-popes), there are articles dealing with the various institutions, customs, councils, political movements, and doctrines. One can turn to this volume, for example, for an authoritative summary of the types of documents issued by the Vatican, or a useful account of the changing shape and status of the Papal States. Each entry concludes with a bibliography of key sources and secondary studies (primarily in Western European languages other than English). A number of useful illustrations and maps also are provided.

However, a few topics that one might expect to find described in greater detail are not included. This reviewer was somewhat surprised by the relatively small amount of coverage (in the form of separate articles at least) of some key councils such as Pisa and Basel which, though deemphasized as sources of authority by the papacy today, were very important in the history of the institution. Likewise, an article summarizing the relations of the papacy with individual countries would have been valuable, although it would, of course, have required the addition of a great deal of labor to what was already an ambitious undertaking. More serious, perhaps, is the lack of an index or table of contents, not entirely compensated for by a generous number of cross-references in the text. As a result, users who do not 
have time to browse the work may miss such useful, but rather specifically titled articles as "'Silence' de Pie XII," "Sac de Rom," or "Helsinki."

In any case, however, this represents an important new addition to the literature, one that belongs in any advanced research collection dealing with the history of the church or European history in general. It also is an item that many scholars may want to consider adding to their personal collection.-R.H.S.

Kadel, Andrew. Matrology: A Bibliography of Writings by Christian Women from the First to the Fifteenth Centuries. New York: Continuum, 1995. 191p. \$29.95. (ISBN 0-8264-0676-9.) LC 94-30157.

This bibliography by a librarian at Union Theological Seminary in New York will be an invaluable addition to all reference collections supporting undergraduate and graduate research in history and the humanities. It lists some 250 Christian women writing up to 1500 Christian Era whose work has appeared in print since 1800. Writing is defined liberally to include the recorded testimonies before inquisitors, chronicles and letters; and Christian is defined to include "all women who would have regarded themselves as Christian, whether their writings are religious or not". (Introd.). Nine chapters range from "Earliest Writings of Christian Women" to "Byzantine Empire and the East" to "Letters and Occasional Writings of the Fifteenth Century." Entries for each woman provide a biographical note, followed by citations to critical editions, translations, and works in anthologies. Most entries list only primary sources, but in some cases, especially when authorship is disputed, secondary sources also are cited. The volume is completed by a brief list of writers whose works have not been published since 1800 , a bibliography of secondary sources, and alphabetical and chronological indexes.-S.S.
Kaganoff, Nathan M. Judaica Americana: An Annotated Bibliography of Publications from 1960-1990. Brooklyn, N.Y.: Carlson, 1995. 2 vols. 917p. \$150. (ISBN 0-926019-75-9.) LC 95-4450.

Judaica Americana is a two-volume bibliography containing more than 7,000 annotated entries of monographic and periodical literature published between 1960 and 1990 on American Jewish history, including the United States, Canada, and Latin America. This monumental effort is the work of Nathan Kaganoff, a foremost bibliographer of American Jewish history and past librarian of the American Jewish Historical Society.

Judaica Americana supplements two full-scale bibliographies: Abraham Simon Wolf Rosenbach's chronological listing of works published up to 1850, An American Jewish Bibliography (Baltimore: 1926, 486p.); and Moses Rischin's An Inventory of American Jewish History to 1954 (Cambridge: 1954, 66p.). In addition, supplements to Rosenbach's publication include works by Jacob R. Marcus (Monograph 1, American Jewish Archives, 1954), Edwin Wolf (Essays in Jewish History, 1958, pp. 187-245), and Nathan M. Kaganoff (Jewish Bibliography, History and Literature in Honor of I. Edward Kiev, 1971, pp. 177-209). Another work worth noting also is entitled Judaica Americana, compiled by Robert Singerman and sponsored by the $\mathrm{He}$ brew Union College-Jewish Institute of Religion (Guide BB525). Singerman's is a chronological bibliography of monographs and serials published from 1679 to 1900 covering all aspects of Jewish life in America.

Nathan Kaganoff's Judaica Americana is uniquely arranged into twelve sections, with entries in each section listed alphabetically by author. Under "General Works," Kaganoff includes general works, bibliography, historiography, local history, and periodicals; under the subheading "Special Studies" are biography, cultural life, education, genealogy, medicine, relations with non-Jews, rela- 
tions overseas, sociology, synagogue architecture, synagogue history, and Zionism. This classification system is uneven at times. It is not always evident why entries for works about an artist are included in the "Biography" section whereas similar types of material can be found in "Cultural Life."

Overall, sections such as "Local History" provide a wealth of information not easily found in other resources. The "Periodicals" section includes selected titles and contents or partial contents for issues published during the period covered by the bibliography. Many of these periodical citations are indexed by author and subject, although this can be irritating at times. The index directs the reader to the abstract number for the periodical title, and he or she must then browse through the contents to find the relevant article. In fact, the weakest aspect of this bibliography is the subject index, which lacks subdivisions for topical subjects, such as music or New York City. This makes subject searching cumbersome.

The strength of this work is in the breadth of coverage of the topic and the annotations that distinguish this bibliography from others. The annotations provide a good guide and invite the reader to explore-they personalize the work.

Judaica Americana is an important and significant work bringing together a vast amount of information central to scholars, students, and those individuals interested in American Jewish history.N.E.F.

\section{Popular Religious Magazines of the} United States. Eds. P. Mark Fackler and Charles H. Lippy. Westport, Conn.: Greenwood Pr., 1995. 595p. \$125. (ISBN 0-313-28533-0.) LC 94-7427.

Students of culture and society often find themselves drawn to a study of the periodical press as an abundant, chronologically arranged source of material about the nature and evaluation of a particular phenomenon, movement, or institution.
An informed understanding of the history and point of view of a particular journal or magazine can be equally useful to a reader seeking to make sense of a particular article in that journal or seeking to locate articles representing a particular outlook or group. This is the value of works such as Mott's classic History of American Magazines (1938-68; Guide AD40) or Robert H. Muller's From Radical Left to Extreme Right (2nd ed., 1970-75; Guide AD45n). Given the amount of work involved in this type of research, reference works of this kind are not always easy to find, so any new addition to this genre is always a welcome event.

Written by sixty academic specialists, the work under review here profiles 100 major American popular religious periodicals of the nineteenth and twentieth centuries. It is conceived as a complement to Lippy's Religious Periodicals of the United States: Academic and Scholarly Journals (1986; Guide BC24), issued by the same publisher. This time, as the title suggests, the focus is on publications appealing more to a general or mass audience than those treated in the earlier volume, and hence materials likely to be of even greater value as a source for the study of American religious and cultural history.

An attempt has been made to provide a broad sampling of religious groups, so along with journals from all major branches of the Christian tradition, three Jewish publications and three titles from "Eastern, Oriental, and Non-Western Traditions" also are profiled. The titles surveyed include denominational organs, publications issued by leading evangelists, and interdenominational or general religious magazines. Each entry begins with a brief essay (generally four to five pages in length) describing matters such as the founding and aims of the journal, its institutional affiliation, editorial emphases and points of views, readership, influence, and place in the history of religion in America. The essay is followed by a listing of "information sources" (in- 
dications of where, if anywhere, a given journal is indexed, and of libraries or microfilm vendors from whom a full copy of the text may be obtained) and then basic publication history, including title changes, volume and issue data, publisher and place of publication, editors, and circulation. At the end of the work is a listing, by religious group or movement, of the journals surveyed (the entries themselves are arranged in alphabetical order, but no alphabetical listing of those titles is provided), and a fairly detailed index of names and topics.

Inevitably, a survey of 100 titles can be nothing but a representative sample of the literature. The editors note that approximately 10,000 titles were potential candidates for inclusion in this work. Given that fact, a focus on Christian periodicals alone would have made more methodological sense. However, care has been taken to include many of the key titles of the American religious experience and to represent important currents such as fundamentalism, conservatism, and liberalism, making this a useful addition to research collections specializing in religious studies or American history.-R.H.S.

\section{English Language}

Crystal, David. Cambridge Encyclopedia of the English Language. Cambridge: Cambridge Univ. Pr., 1995. 489p. \$49.95. (ISBN 0-521-40179-8.) LC 94-23918.

At first glance, this ravishingly illustrated book looks more like one of those coffee table books that try to get away with very skimpy intellectual contents, enticing readers with beautiful illustrations. However, this is a good, informative entertainment, which is in fact what the author set out to accomplish.

The encyclopedia covers the English language historically as well as globally, and is divided into six parts: (1) history of the language; (2) vocabulary; (3) grammar; (4) spoken and written English; (5) using English (which discusses regional, social, and personal variation in dis- course); and (6) learning about English. The appendices contain a glossary of linguistic terms bibliography, an index of authors and personalities, and an index of topics.

This work emphasizes popular culture such as word games, the language of advertising, and verbal humor much more than other language discussions such as The Oxford Companion to the English Language, edited by Tom McArthur (1992, xxvii, 1187p.; Guide BD94). The two works meet different needs. For a quick reference to a specific topic, the Oxford Companion might be easier to use, but it tends to give too much space to nonlinguistic general information on a country or literature that could be readily found elsewhere in standard reference books. The Cambridge Encyclopedia is better focused on the language and its varied manifestations both scholarly and popular.-J.S.

\section{French Literature}

Burgess, Glyn S. The Old French Narrative Lay: An Analytical Bibliography. Cambridge, Mass.: D.S. Brewer, 1995. 140p. \$45. (ISBN 0-85991-478X.) LC 9521659.

This analytic bibliography aims to complement Burgess's previously published bibliography devoted to the works of Marie de France (Marie de France: An Analytical Bibliography. London: Grant and Cutler, 1977, suppl. 1986), providing a comprehensive list of editions, translations, and major studies, as well as journal and book articles on the corpus of twenty lays. (The selection of twenty lays is based on Mortimer J. Donovan's The Breton Lay: A Guide to Varieties (Notre Dame, Ind.: Univ. of Notre Dame Pr., 1969, 267p.).

Part I deals with general studies of the genres and part II consists of bibliographies on individual lays. Each entry typically has five to ten lines of notes and citations to reviews. Each bibliography on an individual lay lists manuscripts, editions, translations, and adaptations in the 
English, Spanish, and French languages, as well as critical studies that were published. An effort was made to include as many 1994 publications as possible. Burgess provides name and subject indexes.

Recommended for scholarly collections that include European literature of the twelfth to thirteenth centuries.-J.S.

\section{German Literature}

Baudke, Petra, and Jutta Schulze. Schriftstellerinnen in Berlin 1871 bis 1945: ein Lexikon zu Leben und Werk. Berlin: Orlanda Frauenverlag, 1995. 407p. 58DM. (ISBN 3-929823-22-5.) LC 95206167.

The compilers, each of whom wrote a dissertation on German women writers, have produced both a useful bibliography and a work of true scholarship. Based on much original research, this biographical dictionary provides one- to two-page biographies (often accompanied by photographs) of some 200 women writers who lived in Berlin between 1871 and 1945. For each entry, this scrupulously documented work also lists archival sources (when available), major secondary sources, and a list of the author's works. The book has a fascinating variety of authors, from those producing sentimental children's stories to bestselling authors and avantgarde poets. Few of the authors are well known now, but this dictionary provides a fascinating glimpse into the literary life of Berlin during this politically important and artistically vibrant period. It should be of interest not only to those working in German literature, but also to anyone researching modern German social and intellectual history and European women's history.-M.C.

Jacob, Herbert. Deutsches Schriftstellerlexikon: 1830-1880. Berlin: Akademie Verlag, 1995. V.1, A-B. 248DM. (ISBN 3-05-002120-9.) (In progress.)

Karl Goedeke's Grundriss zur Geschichte der deutschen Dichtung aus den Quellen
(Guide BE1218) is the basic bibliography in German literature, a towering achievement of German nineteenth-century scholarship. Although the published work only covers literature through 1830 , Goedeke planned to include more of the nineteenth century and had begun to compile material. This work was continued after his death, and in 1929 the Preussischen Akademie der Wissenschaften began planning a nineteenthcentury supplement based on the work of Goedeke and his successor, Franz Munker, under the direction of Georg Minde-Pouet. The first Lieferung appeared in 1940, but, unfortunately, most of the unpublished work was lost or destroyed during World War II, and many of the compilers did not survive. Finally, volume I (A-Ays), including a revision and updating of the 1940 Lieferung, appeared between 1955 and 1962 (Guide BE1218n), but this effort did not continue.

The present volume is a further effort to bring the work of Goedeke into the later nineteenth century, although in a somewhat different form. The compilers have attempted to include all literary figures who were first published between 1830 and 1880 . The entries are much briefer than the more selective and bibliographically exhaustive Goedeke (and MindePouet). Ludwig Anzengruber's entry, for example, is 165 pages in Minde-Pouet's supplement and fourteen pages in the present work. But the current volume lists many more authors than the earlier attempt and refers the reader to many additional sources, including Minde-Pouet.

There are two types of entries, based on the importance of the author. The more complete Personalbibliographien includes birth and death dates, brief biographical information, references to fulllength biographies and standard biographical sources, references to sources of secondary literature, a list of the author's works (though not including different editions and translations, which is available in Goedeke), and references to 
major archival collections. The briefer entries include the authors' dates (when known) and refer the reader to standard biographical sources. This is an indispensable work for any library supporting German literature.-M.C.

\section{Dance}

Getz, Leslie. Dancers and Choreographers: A Selected Bibliography. Wakefield, R.I.: Asphodel Pr., 1995.305p. \$24.95. (ISBN 1-55921-108-3.) LC 94-12129.

This elegantly produced bibliography lists citations to books and articles written in the twentieth century about ballet and modern dancers and choreographers. The articles indexed are from the more scholarly journals, so, with a few exceptions, material from sources such as Dance Magazine, Dancing Times, and Dance and Dancers is not included. Most of the articles are in English. This reviewer found some French, but no Russian or German items, which does eliminate some major untranslated works.

Entries are arranged alphabetically, with birth and death dates. There is a brief bibliography at the end with selected reference works and histories of dance, which is a very useful introduction to the field. Dance as an area for scholarship is a recent development, and it lacks the reference sources available in the other arts. This bibliography is an important addition to the field.-M.C.

\section{African American Studies}

Christian, Charles M. Black Saga: The African American Experience. Boston: Houghton Mifflin, 1995. 608p. \$35. (ISBN 0-395-68717-9.) LC 95-3599.

Jenkins, Everett Jr. Pan-African Chronology: A Comprehensive Reference to the Black Quest for Freedom in Africa, the Americas, Europe and Asia, 1400-1865. Jefferson, N.C.: McFarland, 1996. 440p. $\$ 49.95$. (ISBN 0-7864-0139-7.) LC 958294.

Several African American history chronologies have recently appeared, includ- ing Thomas Cowan's Timelines of AfricanAmerican History: 500 Years of Black Achievement (New York: Berkeley Publishing Group, 1994), Sharon Harley's The Timetables of African-American History: A Chronology of the Most Important People and Events in African-American History (New York: Simon \& Schuster, 1995), and Alton Hornsby's Milestones in 20th-Century African-American History (Detroit: Gale Research, 1993). The two titles under review enrich the group with their own unique perspectives.

Black Saga documents the African American experience in the United States from colonial times to the present in brief entries arranged in chronological order. The people, places, and events are interwoven with concise analyses of the demographic, social, economic, and political trends that affected blacks. The content is enhanced with clear headings, captioned illustrations (photographs, maps, historical documents), and sidebars containing relevant summary data. It is a visually pleasing book.

Pan-African Chronology puts the African American experience (through 1865) into a worldwide context. Relevant historical facts for Africa, the Americas, Europe, and Asia follow the information for the United States; a section entitled "Related Historical Events" concludes each year's entries. For any given year, many of the same facts are recounted as in Black Saga, but often with more detail. Moreover, entries describing historical events are often followed by interpretative comments.

Both books have an extensive index and a bibliography, and both authors, but especially Jenkins, are sensitive to the black perspective and conscious of the problems caused by insensitive, stereotyping terminology.

Because of the different time periods covered and the added geographical dimension of Pan-African Chronology, it would not be redundant for a library to acquire both books.-O.dC. 
DuPree, Sherry Sherrod. African-American Holiness Pentecostal Movement: An Annotated Bibliography. Religious Information Systems, 4. Garland Reference Library of Social Science, 526. New York: Garland, 1996. 650p. \$95. (ISBN 0-8240-1449-9.) LC 94-20225.

Membership in the African American Holiness, Pentecostal, and Charismatic congregations today exceeds seven million people; their written and oral testimony over the course of the past century constitutes an invaluable historical resource.

Sherry DuPree has harnessed that resource for scholarly users. She has identified, located, organized, and described an important segment of a hitherto littleknown and elusive literature documenting the history of the black church in America. The bibliography is limited to information, excluding the area of theology, by and about African American Pentecostalism from the 1880 s to the present. It is arranged to help the user distinguish among Pentecostalists, Holiness people, and Charismatics-and even their subsets. It lists not only the common types of secondary sources (books, articles, dissertations), but also includes references to materials such as convention souvenir booklets, plays, FBI reports, gospel records and music books, WPA reports, and oral interviews. In a word, there is a clear attempt at comprehensiveness.

The entries are annotated, and, most important, the place holding the item is indicated. Much of the material is stored in the DuPree African-American Pentecostal and Holiness Collection at the Schomburg Center for Research in Black Culture, New York Public Library.

Maps, a comprehensive index as well as a geographical one, and several appendices make this bibliography an outstanding piece of research.-O.dC.

Encyclopedia of African-American Culture and History. Eds. Jack Salzman, David Lionel Smith, and Cornel
West. New York: Simon \& Schuster Macmillan, 1996.5 vols. 3203 p. $\$ 450$. (ISBN 0-02-897345-3.) LC 95-33607.

The classic one-volume Encyclopedia of Black America (New York: McGraw-Hill, 1981), which has served librarians and readers as a quick lookup tool for more than a decade and a half, now has been supplanted by a superb new work-the Encyclopedia of African-American Culture and History. This five-volume encyclopedia is bigger in scope and truly outstanding in scholarship, clarity, and visual appeal. Conceived in 1989 to fill a perceived gap in accurate, easily accessible knowledge on the history and culture of African Americans, the encyclopedia set its task to "present the lives and significance of African Americans in the broadest possible way" (Pref.). Its emphasis is therefore on biographical information; about two-thirds of the 2,200 entries are for persons, both historical and contemporary. The remaining entries deal with events, historical eras, legal cases, areas of cultural achievement, professions, sports, and places. There are entries for each of the states as well as for cities of significance to blacks. Several interpretive essay-length articles contributed by wellknown experts in the field on broad topics (e.g., literature, intellectual life) and on key issues in African American history and culture add depth and scholarly analysis to this compendium of factual information. All articles are signed; cross-references to related entries are embedded in the text. The more than 1,000 captioned illustrations, the bibliographies concluding each entry, and an appendix with tables, charts, and other statistical data, as well as a breakdown of biographical entries by profession, a thorough back-of-the-book index, enhance the work's usefulness and appeal. Every library should own this work.-O.dC.

Fabre, Michel. The French Critical Reception of African-American Literature from 
the Beginnings to 1970: An Annotated Bibliography. Bibliographies and Indexes in Afro-American and African Studies, 33. Westport, Conn.: Greenwood Pr., 1995. 310p. \$75. (ISBN 0-31325368-4.) LC 95-12543.

The first real reviewing of African American literary production in France began in 1844 when audiences welcomed the romantic dramas of Victor Sejour. Over the course of the next 125 years, many other African American writers found receptive readers in France. It is to enrich the bibliographies of these individual writers, as well as to chart the critical reception of this specific body of literature abroad, that Michel Fabre has compiled this book.

The bibliography focuses on responses to creative writers and excludes from its scope reactions to political, sociological, historical, and other studies, except when written by primarily creative writers. The exceptions are responses to writings of prominent political leaders such as Martin Luther King Jr., Malcolm X, and Eldridge Cleaver.

The bulk of the items selected for inclusion were published between 1900 and 1970 , and were all printed in French. The arrangement is chronological by year and then alphabetical within each section. There are separate indexes for authors and concepts, titles, and periodicals, as well as a list of translations and original publications of African American literature in France until 1970.

By the compiler's own admission, the work has many lacunae, chiefly because indexes to French periodicals and newspapers are rare, and newspaper and journal holdings of French libraries are often incomplete. Stress has been placed on accuracy; therefore, only items that were actually read are included in the bibliography.

Because no other reference book covers this information, it is a worthwhile acquisition for libraries with African American studies collections.-O.dC.
Hardaway, Roger D. A Narrative Bibliography of the African American Frontier: Blacks in the Rocky Mountain West, 1535-1912. Studies in American History, 9. Lewiston, N.Y.: Edwin Mellen Pr., 1995. 242p. \$89.95. (ISBN 0-77348879-0.) LC 95-16888.

This bibliography evolved out of a doctoral dissertation project, hence from the outset the author was obliged to conceive of a work that would make a unique contribution to the field of African American studies.

A Narrative Bibliography of the African American Frontier makes its contribution in both choice of subject and treatment of the material. The author's selection of the Rocky Mountain Region-specifically, the states of Arizona, Colorado, Idaho, Montana, Nevada, New Mexico, Utah, and Wyoming-fills a gap in our knowledge about the African American frontier experience. Scholars have tended to focus on other western states, such as Kansas, Texas, and California, where the black presence was more pronounced.

Designed to be more of a story to be told rather than a list to be enumerated, the bibliography is divided into fifteen subjectspecific chapters. Each chapter opens with a background narrative, and each entry is accompanied not only with an annotation but often with further explanatory text, making each chapter a "narrative whole rather than merely a collection of annotated sources" (Introd.). It is not a definitive bibliographic study as it limits itself to books and journal articles, but it is thorough and accurate because the author examined and evaluated each item included. The book is accompanied by state, journal, subject, and author indexes.

An unexpected feature of the bibliography is its inclusion of references to sources for young readers. Though this was done primarily to include the serious high school student, sometimes these are the only works available on the subject.

This bibliography is a fine piece of research, eminently readable and valu- 
able in its coverage of a little explored topic in the history of African Americans.-O.dC.

Henritze, Barbara K. Bibliographic Checklist of African American Newspapers. Baltimore: Genealogical Publ., 1995. 206p. \$35. (ISBN 0-8063-1457-5.) LC 9479984.

Building on Warren Brown's Check List of Negro Newspapers in the United States, 1827-1946 (Jefferson City, Mo., 1946, 37p.) and drawing on 106 additional reference sources, Barbara Henritze brings us - exactly 50 years later-a compilation of more than 5,539 titles, ten times the number listed in Brown's pioneering work.

Included in this comprehensive listing are newspaper and assorted periodical titles (the latter included whenever they were listed in the source consulted by the compiler) published beginning with the early decades of the nineteenth century through the present in forty-four states and the District of Columbia, and either owned, published, edited, and/or read predominantly by African Americans.

Arranged alphabetically by state and city (there is a title index), the title entries include information on the frequency and time span of publication, and note the source in which mention of the title was found. Although no attempt is made by the compiler to indicate the actual whereabouts of the newspapers on the list, clues to repositories are often found in the originating source. Moreover, in the Introduction, Henritze provides indispensable information to the prospective researcher about locating old newspapers. The work is enhanced by an extensive bibliography of works relevant to the study of the African American press.

Because of the indispensable nature of newspapers to historical and genealogical research, and because of the lack of attention hitherto paid to black newspapers, this compendium of information culled from a multitude of existing bibli- ographies and directories is an invaluable contribution to the field of African American studies.-O.dC.

\section{Women's Studies}

Women's Resources International [CDROM]. Baltimore: National Information Services Corp. (NISC), 1996- . Semiannual updates. \$895/year.

This CD-ROM combines several women's studies resources: Women Studies Abstracts (1954- , Guide CC532); Women's Studies Database (compiled by Jeanne Guillaume, University of Toronto, 1972- ); Women of Color \& Southern Women (1975- , Guide CC623); Women's Health and Development: An Annotated Bibliography (from the World Health Organization); and several publications of the Women's Studies librarian at the University of Wisconsin: New Books on Women \& Feminism, 1979- , Guide CC520); Women, Race, and Ethnicity: A Bibliography, 1970-1990 (1991; Guide CC625); WAVE: Women's Audiovisuals in English: A Guide to Nonprint Resources in Women's Studies, 1985-1990 (1991, 88p.); History of Women and Science, Health, and Technology: A Bibliographic Guide to the Professions and Disciplines, 1970-1992 (1993; Guide EA231).

The majority of the records come from the Women's Studies Database $\mathbf{5 2 , 0 0 0}$ records), which includes some essays published in books, and Women Studies Abstracts (30,000 records). The indexing is quite good, and abstracts from the latter are included. Because this is primarily an index of the feminist press, it is an excellent resource for finding articles from a feminist perspective (drug testing of pregnant women, for example, or reviews of Katie Roiphe's The Morning After or articles about body image).

The search software is very flexible, with novice, advanced, and expert search systems including all the features one would expect: boolean searching, truncation, the ability to limit by fields, and a variety of printing and downloading options. There is some problem with collo- 
cation; the records from the two largest databases seem to have merged quite easily but the records from the Women of Color $\mathcal{E}$ Southern Women database do not seem to have merged with the others and often appear as duplicates.

An online thesaurus is coming and is not part of the first issue. Although this is not the first women's studies index to appear on CD-ROM, this database is far more useful. It goes back farther than the Women's Studies On-Disc (Boston: G.K. Hall, Macmillan, 1995- . \$495) which only goes back to 1989 , and is more extensive, with better indexing and abstracts.-S.S.

\section{Folklore}

El-Shamy, Hasan M. Folk Traditions of the Arab World: A Guide to Motif Classification. Bloomington: Indiana Univ. Pr., 1995. 2 vols. \$75. (ISBN 0-253-352010.) LC 95-1424.

An Arab counterpart to Stith Thompson's Motif-Index (Guide CF49), it starts with the classification system devised by Thompson and expands it to include "facets of culture and society other than those explicitly expressed in folk-literature" (Introd. to vol. 1), as well as the use of some concepts in cognitive psychology such as "empathy" and "fealty" as indexing terms.

The first volume presents systematically classified motifs, their geographic presence, and source materials that include collections, field recordings, and manuscripts. The second volume is an alphabetical index. A bibliography at the end of volume 1 lists printed and archival resources cited in the index. A table of geographic locations of tale types is found in volume 1 (pp. 415-41).

This type of data could have been more effectively presented in a CD-ROM format for ease of access and quicker retrieval (such as Stith Thompson is now, see Guide (F49n). It is suggested that the publisher would consider offering this index in computer-readable form and would include some representative texts of source documents. Meanwhile, this printed index is a valuable addition to both folklore and Islamic studies collections.-J.S.

\section{Economics}

Damodaran, Aswath. Investment Valuation: Tools and Techniques for Determining the Value of Any Asset. New York: John Wiley, 1996. 519p. \$60. (ISBN 0471-13393-0.) LC 95-7418.

This book explores what the author considers the three main methods for valuing an asset: valuation using discounted cash flows; relative valuation, which looks at comparable assets; and contingent claim valuation used mainly in valuing options. The bulk of the volume is devoted to valuing either a firm or the equity and debt issued by a firm.

The subtitle is somewhat misleading as there is only one chapter on valuing real estate and one chapter on valuing various other types of assets. The author argues that the techniques that work in valuing financial assets, largely stocks, can be applied to valuing any other asset.

Each chapter begins with a statement of the questions to be discussed and ends with a conclusion restating the result of the inquiry. There also are "Questions and Short Problems" after each chapter, making the book usable as an academic text as well as a reference book. The sections and subsections of each chapter have their topic heading in boldface making it easy for the reader to home in on a discussion of a specific point. The chapters that involve computations, such as "Understanding Financial Statements," are studded with formulas in boldfaced boxes and with illustrations based on corporate filings from the early 1990 s. The text also contains many charts and graphs illustrating specific points.

The author addresses practical questions such as, How does one estimate a firm's future growth rate? or How do financial markets account for the tax sta- 
tus of the earnings or cash flow that a firm generates? At the same time, he is clearly very familiar with the academic literature on valuation and financial markets. There are numerous references in the text to important studies of securities valuation or to published work describing innovative techniques. The author strives to present all significant valuation methods and to assess the advantages and disadvantages of each. This thoroughness makes the book a useful overview of valuation techniques for the business student or the serious investor.

Much of the volume assumes a basic knowledge of statistics. However, the writing is lucid enough that the reader can grasp the author's main points without any background in statistics.

There is an occasional undefined term in the text. The index is no more than adequate, and there is no glossary of terms. Nevertheless, this book is a worthwhile addition to any finance collection in an academic or large public library.-H.G.

\section{Political Science}

Manzo, Bettina. The Animal Rights Movement in the United States, 1975-1990: An Annotated Bibliography. Metuchen, N.J.: Scarecrow, 1994. 296p. \$39.50. (ISBN 08108-2732-8.) LC 94-19622.

This bibliography lists 1,322 items in a wide variety of material in terms of both format and approach concerning activities of animal rights organizations, ideas, and issues - newspaper articles, government documents, law reviews, trade journals, science journals, among others. Most items are accompanied by three- to tenline notes. The bibliography is divided into nine chapters that cover topics such as philosophy, ethics, and religion; law and legislation; factory farming and vegetarianism; fur industries; use of animals in entertainment such as circuses and horse racing; and animal experimentation.

It is unfortunate that this bibliography stops at 1990 , because many legislative measures were enacted in the early 1990 s, some especially to curb what was regarded as the excesses of "animal liberation" movements. Some updating, perhaps in the form of a supplement, would be useful. Another area for expansion is the animal rights movements in international contexts. The author has already included some foreign publications in English. It would be important to look at movements globally, because animal trade, whether for food, garment, or tool of research, is not confined to the United States.-J.S.

\section{History}

Cassell Dictionary of Modern Britain. Eds. Tanya Joseph and D. J. Sagar. London: Cassell, 1995. 306p. £29. (ISBN 0304-34588-1.)

History Today Companion to British History. Eds. Juliet Gardiner and Neil Wenborn. London: Collins \& Brown, 1995. 840p. \$40. (ISBN 1-85585-1784.)

Gascoigne, Bamber. Encyclopedia of Britain. New York: Macmillan, 1993.720p. \$110. (ISBN 0-02-897142-6.) LC 931881.

Twentieth Century Britain: An Encyclopedia. Ed. F. M. Leventhal. Garland Reference Library of Humanities, 1378. New York: Garland, 1995. xxxviii, 902p. \$95. (ISBN 0-8240-7205-7.) LC 9530749.

Whereas in the past researchers found a dearth of dictionaries on Britain, now we have almost an embarrassment of riches. Most of the books produced here are compiled by people to address a definite need in their work or to benefit the readership of a journal.

The History Today Companion covers from the Roman invasion to around 1979, with articles updated beyond that to the 1990s. Six historians, assigned specific time periods, made up a good proportion of the articles with a few other specialists making contributions. The articles vary in length from a paragraph (Aelfthryth) to half a page (Agadir Crisis) to several pages (agriculture). The arrangement is 
alphabetical. The articles are unsigned; and there is neither a bibliography nor an index, although there are cross-references in small capitals.

Bamber Gascoigne's Encyclopedia of Britain, on the other hand, grew out of questions for a quiz program and is meant for quick lookups. (For the 1993 edition, see Guide DC292.) The articles are usually about one to two paragraphs in length, and cover a wide range of topics including current events, television, and literature (Abbey Road, Admiral's Men, Abide with $\mathrm{Me}$ ). The illustrations are handsome. Cross-references are starred, but there is no index; there is a short bibliography. The articles are unsigned, which implies they were written by Gascoigne.

The compilers of the Cassell Dictionary of Modern Britain are with CIRCA, a group responsible for Keesings Record of World Events (Guide DA187) and the Cassell Dictionary of Modern Politics (1994,340p.). The period of coverage is 1945 to mid-1995. Articles are unsigned, with a paragraph or so usually for identification or definition (ABC Trial, Advertising Standards Authority, Agenda 21, AK-47), though a few are longer (about a column) and more substantive (major and majorism, punk rock). Cross-references are in boldface within the body of the article, and there is an Index of Personal Names. The appendices present tables of senior government members since 1945, general election results from 1945 to 1992, and countries of the empire granted independence since 1945.

The fourth of these dictionaries is meant for researchers. Twentieth Century Britain offers articles of 500 to 3,000 words (abortion, The Cabinet, Camden Town Group) written and signed by scholars, with four- to five-entry bibliographies at the end of each. Cross-references are in boldface, the index is well done, and the "Guide to Further Research" is a two-page listing of reference books by format. To enhance use of the volume, the compilers have added a breakdown of the entries into 20 broad topics (e.g., art and architecture, communications, foreign and imperial relations). The volume concludes with a chronology 1900-1994, with four to ten entries listed for each year. Because this volume is considered an extension of the Garland dictionary, Victorian Britain (Guide DC337), one hopes that other periods will be similarly covered.

So which to use? For identification or definition, Gascoigne's work would be a good starting point unless one is seeking focus on an earlier period, in which case the History Today volume would be the better resource. For a survey, one should use the History Today Companion.

For the twentieth century, though, Gascoigne's work would be appropriate for popular culture; for political and economic questions, one should use the Cassell dictionaries. Finally, for someone beginning research or for a scholar wishing to review a topic, readers would be very well served by the Garland.-E.M.

\section{A Companion to American Thought. Eds.}

Richard Wightman Fox and James T.

Kloppenberg. Oxford: Blackwell, 1995. 840p. \$95.40. (ISBN 1-557862680.) LC 94-13002.

This past year, Blackwell has published a number of very good reference works, such as dictionaries of religion, metaphysics, evangelicals; the volume under review here is another very useful one. The Companion to American Thought states that the goal of the compilation is "to help students, scholars and general readers deepen their knowledge of the major concepts and thinkers in the diverse traditions of American thought, and to become acquainted with key debates in the contemporary intellectual life of the United States" (Introd.) from "Abortion" to "Youth." Thus, there are essays of between 1,000 and 2,000 words for the most important articles (for example, baseball, frontier, Margaret Fuller, fundamentalism, Clifford Geertz, and guilt). The 
shorter articles of about 100 words (for example, ashcan school, Armory show, Robert Frost, Sarah Grimke) are meant "to signal their existence and to suggest their value for future study."

American thought is hard to define, but here it is interpreted broadly to mean "key ideas and thinkers in history, literature, religion, philosophy, political theory." Literature is included "on the grounds that authors of fiction and poetry have often contributed to thought as well as literature."

An article offers informed discussion, with emphasis on its relation to the discourse in contemporary life, cross-references at the end of the article, and a short bibliography called "Suggestions for Further Reading" - and it is signed. The index is thorough, with major articles given in boldfaced page numbers. Inevitably, there will be questions about inclusions and exclusions. For example, why include Christopher Lasch (one of the contributors) but not his father-in-law, Henry Steele Commager? Why not Samuel Eliot Morison?

By and large, the entries are well written and the concept behind the undertaking is extremely relevant. Already our beginning students have found the volume and put it to good use. - E.M.

\section{Encyclopedia of Latin American History} and Culture. Ed. Barbara A. Tenebaum. New York: Scribner's Macmillan, 1996. 5 vols. ill. \$449. (ISBN 0-684-19253-5.) LC 95-31042.

Similar in scope, arrangement, and content to other subject encyclopedias being published (e.g., Encyclopedia of African American History and Culture), the Encyclopedia of Latin American History and Culture covers life in some twenty different countries in 5,287 articles. More than half (about 3,000 ) of the entries are biographical and the Appendix biographies offer twenty-one categories by occupation or field of activity (e.g., outlawry, visual arts). The articles are well written by scholars, thorough, are signed, have crossreferences at the end of each, as well as with short bibliographies. The subject index includes reference to the illustration, the tables, and the graphs. An article on a country gives a survey of its political history by period, then treats various important constitutional documents, its geography, movements, organizations, political parties, and so on. Smaller articles, such as "Water Witch Incident" or "Llanos," are thorough with bibliographical references. There are some unfortunate gaps-for example, there are no articles on libraries or archives and no mention of them in the index.

Still the encyclopedia fulfills its stated aim: "To organize current knowledge of the region for the literate and curious public" (Pref.).-E.M.

\section{New Editions and Supplements}

The sixth edition of Walford's Guide to Reference Material is now complete with volume 3, "Generalia, Language \& Literature, The Arts" (compiled by Anthony Chalcraft, Ray Prytherch, and Stephen Willis. London: Library Assoc., 1995, 1148p., £130; 5th ed. Guide AA363). The bibliography has about 8,700 entries of which 1,500 are new, and includes many references in the critical annotations (though these are not indexed). The emphasis is still English language, the arrangement is still UDC classification, and the series is still very authoritative. Electronic resources are included, though here one can quibble at exclusions-for example, OCLC but not RLIN, no mention of First Search or CitaDel. The indexing is thorough, and there is a separate Online and Database Services Index. This a major reference tool.

The Bibliographie der Autobiographien, compiled by Jens Christian Jessen (Guide AH214), adds doctors to its coverage with volume 4, Selbstzeugnisse, Erinnerungen, Tagebucher und Briefe deutschsprachiger Artze (Munich: Saur, 1996, 630p., \$160). Other professions covered in earlier volumes 
have been mathematicians and other scientists, artists, writers, and engineers.

Several biographical dictionaries have been expanded and updated: Who Was Who in Egyptology?, 3rd revised edition by M. L. Bierbrier (London: Egypt Exploration Society, 1995, 458p., £62; 1st ed., comp. Warren R. Dawson and Eric P. Uphill, 1951; 2nd rev. ed., 1972) has added portraits for each entry in the "Biographical Index of Egyptologist; of Travellers, Explorers, and Excavators in Egypt; of Collectors of and Dealers in Egyptian Antiquities; of Consuls, Officials, Authors, Benefactors and others whose names occur in the Literature of Egyptology, from the year 1500 to the present day, but excluding persons now living" (verso of title page).

David Quinlan's Illustrated Directory of Film Character Actors (London: Batsford, 1995, 384p., £25; 1st ed. 1985 Guide $\mathrm{BH} 284 \mathrm{n}$ ) has added up to 1995 to the filmographies of each actor. The work still offers thumbnail sketches of the person, which makes the volume fun to read (e.g., Una Merkel, prettily pixieish; and Jan Merlin with mean eyes and a hyena smile).

Robert S. Wistrich, Who's Who in Nazi Germany (London: Routledge, 1995, 296p., $£ 17$; 1st ed. 1982) is updated with new information added. The coverage is not only for known Nazis but also those who suffered (e.g., Emil Nolde, Kurt Weill). The volume addresses only Germans, not Austrians or others in Central Europe.

Growing from 504 entries in the first edition to 777 bibliographies in the second (or 1,268 entries counting the crossreferences), William Wortman's Guide to Serial Bibliographies for Modern Literature (New York: MLA, 1995, 300p., \$37.50; 1st ed. 1982. (Guide BE34) aims to include "all current serial bibliographies that cover national literatures, literary periods, genres, themes and subjects and literary authors" (Introd.). Current means from about 1960 to the present. "All the bibliographies with electronic formats are also listed separately in the appendix with place of publication." Additions and corrections are now maintained in a file on the Internet: http:/ /lib.muohio.edu/serials-bibliographies (corrected from the URL given in the introduction).

John R. Hinnells compiled the Penguin Dictionary of Religions (Guide BC73) in 1984. The revised edition has been retitled A New Dictionary of Religion (Oxford: Blackwell, [1995], xxxvii, 760p., \$74.95) and now is compiled with the assistance of sixty-five contributors (formerly twenty-nine). The text has been extensively expanded to include new sections (e.g., Afro-Caribbean religious movements, Hinduism in the Caribbean, implicit religion), completely rewritten topics (e.g., study of religion, Buddhism), and updated entries to emphasize movements, developments, and practices (e.g., religious pluralism). The bibliography (pp. 577-676), compiled by Nora Kirby with references supplied by the contributors, is arranged in broad topics (e.g., American religions, astrology). Each entry in the text explicitly refers to one of these sections in the bibliography. A list of contents by subject area and by author concludes the volume.

A Guide to the Contents of the Qur'an (Reading, Penn.: Garnet, 1995, 245p., $\$ 55.00)$, compiled by Faruq Sherif, is a new printing of the 1985 edition (London: Ithaca Pr.) with some additional material. Although the contents are more or less the same, libraries that own the 1985 edition will want to purchase this edition because it is printed on better paper using a larger font.-J.S.

The continuation of Harriet Semmes Alexander's American and British Poetry (Guide BE488) adds coverage for 1979 to 1990 (Athens, Ohio: Swallow/Ohio Univ. Pr., 1996, 450p., \$65). A new category within each poet's section called "General" provides for references to substantial information on the poet's work as a whole, but not on a specific poem. There are an author/title index and a list of sources. 
Black African Literature in English 1987-1991 continues the coverage (London: Hans Zell, 1995, 682p., \$125; see Guide BE1506 for earlier volumes) and includes some earlier materials omitted from previous volumes. No creative works are included unless they have a substantial preface, though bibliographies of creative work are cited. Still in two partsgenre and topic, and individual authorthe bibliography cites 9,000 books, essays, and those journal and newspaper articles with literary significance.

This second edition of Blacks in Black and White: A Source Book on Black Films by Henry T. Sampson (Metuchen: Scarecrow, 1995, 735p., \$89.50; 1st ed. 1977) offers much new information: new chapters ("Whites in Blackface: The Emerging Black Image in American Films"), expanded chapters (Oscar Michaeux and other producers), updated biographical sketches, expanded entries for black film companies, and new titles in the filmography. Also new is appendix C, which lists theaters in the United States that catered to black patronage. This compilation is a labor of love.

The Cambridge Guide to Theatre by Martin Banham (Cambridge, England: Cambridge Univ. Pr., 1995, 1250p., \$49.95) is the revised edition of The Cambridge Guide to World Theatre (1988; Guide BH67). An updating, the dictionary also includes new entries and major rewriting (African theatre, liturgical drama, the biographies). Articles are signed with initials, which are spelled out in a four-page list of contributors and their affiliations. There is a list of less-obvious entries, such as boulevard, hunger artist, stage food.

Since the mid-1970s, Manchester University Press has published a bibliographic series most useful for undergraduates because it emphasizes English language material and is selective: History and Related Disciplines: Select Bibliographies. Several new editions and new titles have been published within the last year: Ancient Greece and Rome, compiled by Keith Hopwood (1995, \$79.95), with 8,000 entries covering c. $950 \mathrm{BC}$ to AD 565; however, it is not as strong on literature; British Economic and Social History, compiled by R .C. Richardson and W. H. Chaloner (3d ed. 1996, £69; 1st ed. 1976, 2d ed. 1984; Guide DC272) with a cutoff date of 1980; Western Political Thought, compiled by Robert Eccleshall and Michael Kenny (1995, 342p., \$79.95), treating the publications 1945 to the present for the political thought of the British Isles, continental Europe, and North America.

A new edition of Österreich Lexikon in zwei Banden, edited by Richard and Maria Bamberger, Ernst Bruckmuller, and Karl Gutkas (Wien: Verlagsgemeinschaft Osterreich Lexikon, 1995, 2 vols., il.; 1st ed. 1966-67; Guide DC96) updates both the articles and the bibliography ending each article. Unfortunately, some of the tables have been dropped instead of being updated-for example, the table for the Bundesbudget for 1953, 1961, 1964, or the list of Benedictine cloisters. There is a definite need for an index. A general bibliography has been added (pp. xiv-xvii). Now, if only the Austrians would do a definitive historical bibliography.

K. G. Saur has been publishing a series, Guides to the Sources for the History of the Nations, and part 3 of that series covers North Africa, Asia, and Oceania (Guide DD75). Volume 5, Sources de l'histoire du Proche-Orient et de l'Afrique du Nord dans les Archives et Bibliothèques françaises, of the subseries is an inventory actually covering only North Africa and the Middle East; and part 2, Bibliothèque national, was published in 1984. Part 1 of volume 5 is in three volumes: Archives nationales (vol. 1); Archives departementales municipales et des ministères (vol. 2); and Autres archives (vol. 3) (Munchen: Saur, 1996, 3 vols., $\$ 400)$. 